\title{
NONALCOHOLIC FATTY LIVER DISEASE IN SEVERE OBESE PATIENTS, SUBJECTED TO BARIATRIC SURGERY
}

\author{
Alexandre LOSEKANN 1 , Antonio Carlos WESTON², Luis Alberto de CARLI², \\ Marilia Bittencourt ESPINDOLA², Sergio Ricardo PIONER ${ }^{2}$ and Gabriela Perdomo CORAL ${ }^{1}$
}

\begin{abstract}
Context - Nonalcoholic fatty liver disease encompasses a spectrum of histopathological changes that range from simple steatosis to nonalcoholic steatohepatitis. Works suggest that iron $(\mathrm{Fe})$ deposits in the liver are involved in the physiopathology of nonalcoholic steatohepatitis. Objective - The aim of this study was to determine the prevalence of simple steatosis and nonalcoholic steatohepatitis in patients with morbid obesity, subjected to bariatric surgery and to establish a correlation of the anatomopathological findings with the presence of liver fibrosis. Methods - A total of 250 liver biopsies were conducted in the transoperation of the surgeries. Results - Steatosis was present in $226(90.4 \%)$ of the samples, $76(30.4 \%)$ being classified as mild; $71(28.4 \%)$ as moderate and $79(31.6 \%)$ as intense. Nonalcoholic steatohepatitis was diagnosed in $176(70.4 \%)$ cases, where $120(48.4 \%)$ were mild; $50(20 \%)$ were moderate, and $6(2.4 \%)$ cases were intense. Fibrosis was referred to in 108 (43.2\%) biopsies, 95 of which (38\%) were mild; 2 $(0.8 \%)$ were moderate; $7(2.8 \%)$ were intense, and cirrhosis was diagnosed in $4(1.6 \%)$ cases. There was a correlation between the degree of steatosis and the level of inflammatory activity $\left(r_{s}=0.460 ; P<0.001\right)$ and between the degree of this activity and the degree of fibrosis $\left(\mathrm{r}_{\mathrm{s}}=0.583 ; P<0.001\right)$. Only $13(5.2 \%)$ samples showed Fe deposits. Conclusion - There is a high prevalence of nonalcoholic steatohepatitis in these patients and a positive correlation of the degrees of nonalcoholic steatohepatitis with the intensity of fibrosis. The low prevalence of Fe deposits found makes it questionable that the presence of this ion has any participation in the physiopathogeny of nonalcoholic fatty liver disease.
\end{abstract}

HEADINGS - Fatty Liver. Liver cirrhosis. Morbid obesity. Bariatric surgery. Iron metabolism disorders.

\section{INTRODUCTION}

Obesity is increasing its prevalence at an alarming rate, reaching approximately 300 million people worldwide. Said prevalence is estimated at $20 \%{ }^{(9,12)}$. Nonalcoholic fatty liver disease (NAFLD) is among the biggest complications of obesity. NAFLD encompasses a wide spectrum of histopatological changes ranging from simple steatosis (SS) to nonalcoholic steatohepatitis (NASH), which can evolve to cirrhosis and hepatocellular carcinoma ${ }^{(21)}$. SS is defined as the presence of fatty deposits without hepatocellular damage, while NASH is defined as the presence of steatosis associated with hepatocellular lesion with or without fibrosis ${ }^{(2,3)}$. Some risk factors have been associated with the development of NASH, such as metabolic syndrome, age, obesity and diabetes mellitus $(\mathrm{DM})^{(7,22)}$. The role of the presence of $\mathrm{Fe}$ in liver tissue and its relation with NASH has been the target of countless studies. Small quantities of $\mathrm{Fe}$, found in liver tissue, can act as factor enhanc- ing oxidative stress in the hepatocyte determined by fats, virus and alcohol, increasing toxicity and leading to fibrogenesis and carcinogenesis ${ }^{(17)}$. Mendler et al. established a relationship between the resistance to insulin and the presence of $\mathrm{Fe}$ in liver biopsies of obese individuals ${ }^{(11)}$.

Patients with morbid obesity (MO) underwent to bariatric surgery have been a population in which NAFLD has been much studied, thanks to the possibility of conducting transoperative liver biopsy with low morbidity. The results of this surgery have determined an improvement in the hepatic histopathology of these patients ${ }^{(10,13)}$. On the other hand, the need for liver biopsy in pre-operative evaluation has been the object of discussion, in some selected cases, considering that patients with advanced fibrosis in pre-operation have increased risk of decompensation in the post-operative, increasing morbimortability of this surgical modality ${ }^{(3,14,20)}$.

The aim of this study was to determine the prevalence of SS and NASH in patients with MO, subjected

\footnotetext{
Declared conflict of interest of all authors: none

1 Programa de Pós-Graduação em Hepatologia, Universidade Federal de Ciências da Saúde de Porto Alegre (UFCSPA), Porto Alegre, RS, Brasil; 2 Centro de Tratamento da Obesidade, Hospital Santa Casa de Misericórdia de Porto Alegre, Porto Alegre, RS, Brasil.

Correspondence: Alexandre Losekann. Rua São Francisco 672 - 90062-070 - Porto Alegre, RS, Brasil. E-mail: alosekann@gmail.com
} 
to bariatric surgery in the Obesity Treatment Center of the Santa Casa de Porto Alegre Hospital Complex, and to establish a correlation of the anatomopathological findings (steatosis, inflammatory activity and iron deposits) with the presence of liver fibrosis.

\section{METHODS}

In this retrospective study, a total of 250 liver biopsies were analyzed, conducted in the transoperation of patients subjected to bariatric surgery from 2007 to 2012, in the Obesity Treatment Center of the Santa Casa de Porto Alegre Hospital Complex. Patients aged less than 18 years were excluded, as well as those who presented serological markers for viral hepatitis and those with alcohol intake $>20 \mathrm{~g} /$ day.

The liver biopsies were evaluated by the same pathologist. The histochemical techniques used to analyze the specimen were hematoxylin/eosin (HE), Masson's trichrome (to evaluate fibrosis) and Perls (to evaluate iron deposits). Steatosis was considered to be present on reaching over $5 \%$ of the sample studied. The percentage presence of $5 \%$ to $33 \%$ was considered to be mild steatosis (G1); of $33 \%$ to $66 \%$ as moderate steatosis (G2) and greater than $66 \%$ as severe steatosis $(\mathrm{G} 3)^{(2)}$.

To diagnose $\mathrm{NASH}$, the presence of steatosis associated with hepatocyte ballooning and/or inflammatory infiltrate was deemed necessary. The activity of NASH was classified as mild (A1), moderate (A2) and severe (A3), as described by the Pathology Committee of the NASH Clinical Research Network. The degree of fibrosis was classified as stage 1A, when sinusoidal/discrete cellular fibrosis was identified; degree 1B if sinusoidal/dense and diffuse cellular fibrosis; and $1 \mathrm{C}$ in case portal fibrosis was identified. In stage 2 , pericellular/perisinusoidal fibrosis was considered, associated with periportal fibrosis; in stage 3 , the anterior changes associated with bridging fibrosis and in stage 4 , cirrhosis was diagnosed $^{(1)}$. For statistical analysis, the degree of fibrosis was classified as mild (stage 1A, 1B, 1C), moderate (stage 2), severe (stage 3 ) and cirrhosis (stage 4).

A semi-quantitative analysis of the iron deposits in the hepatocytes and in the Kupffer cells was conducted, according to the classification used by Sebastiani et al. ${ }^{(18)}$ in which degree 0 corresponds to the total absence of Fe; degree 1 to the minimum quantity; degree 2 to mild quantity; degree 3 to moderate quantity and degree 4 to great quantity of $\mathrm{Fe}$.

\section{Statistical analysis}

The data analysis was conducted using the SPSS (Statistical Package for the Social Sciences) software, version 18.0. This sample size supports a minimum difference between groups of $20 \%$, with power of $85 \%$ and significance level of $5 \%$. The continuous variables were described with use of mean and standard deviation and the categorical variables by means of absolute and relative frequencies.

To evaluate the association between the categorical variables, the Pearson chi-square test was applied. For the continuous or ordinal variables, the Spearman correlation test was used.

The statistical significance level considered was $5 \%$ $(P \leq 0.05)$.

This study was approved by the Institutional Review Board of Irmandade da Santa Casa de Misericórdia de Porto Alegre - ISCMPA, with number 70375.

\section{RESULTS}

Out of the 250 biopsies analyzed, $200(80 \%)$ were of women, and $50(20 \%)$ of men, with an average age of 36.8 \pm 10.2 years. The average body mass index (BMI) was 43.6 $\pm 5.2 \mathrm{Kg} / \mathrm{m}^{2}$.

Steatosis was present in $226(90.4 \%)$ samples. With regard to its intensity, it was observed that $76(30.4 \%)$ were classified as mild; $71(28.4 \%)$ as moderate and $79(31.6 \%)$ as intense (Figure 1).

NASH was diagnosed in $176(70.4 \%)$ cases. Mild degree was found in $120(48.4 \%)$ cases; moderate in $50(20 \%)$ cases, and severe in $6(2.4 \%)$ cases (Figure 2).

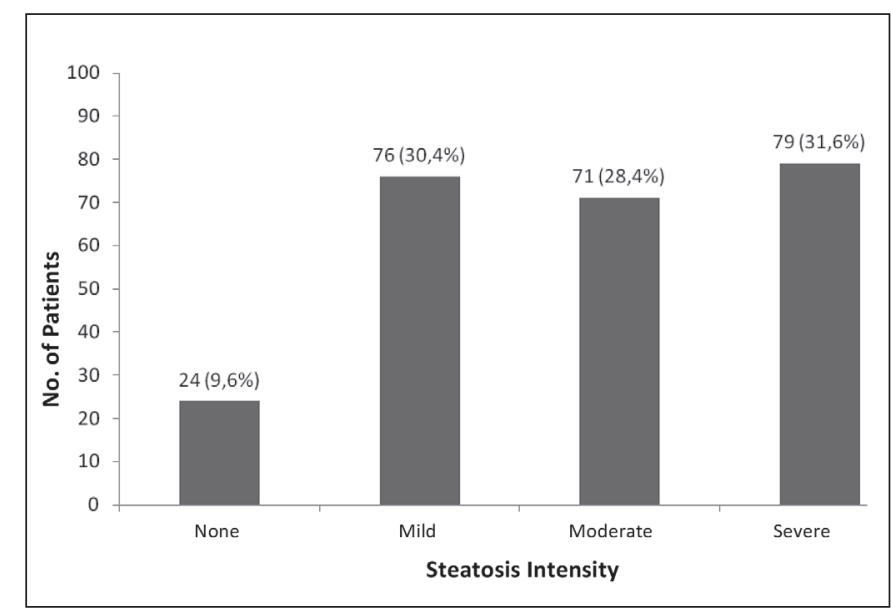

FIGURE 1. Sample distribution with regard to the presence and intensity of steatosis

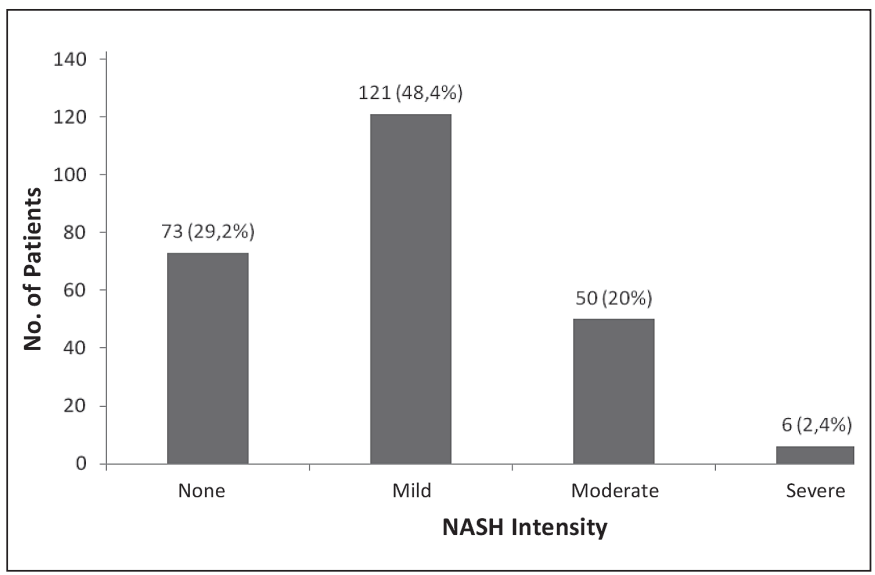

FIGURE 2. Sample distribution with regard to the presence and intensity of nonalcoholic steatohepatitis (NASH) 
Fibrosis was referred to in $108(43.2 \%)$ biopsies, 95 of which $(38 \%)$ were mild; $2(0.8 \%)$ were moderate; 7 were intense $(2.8 \%)$, and cirrhosis was diagnosed in $4(1.6 \%)$ cases (Figure 3).

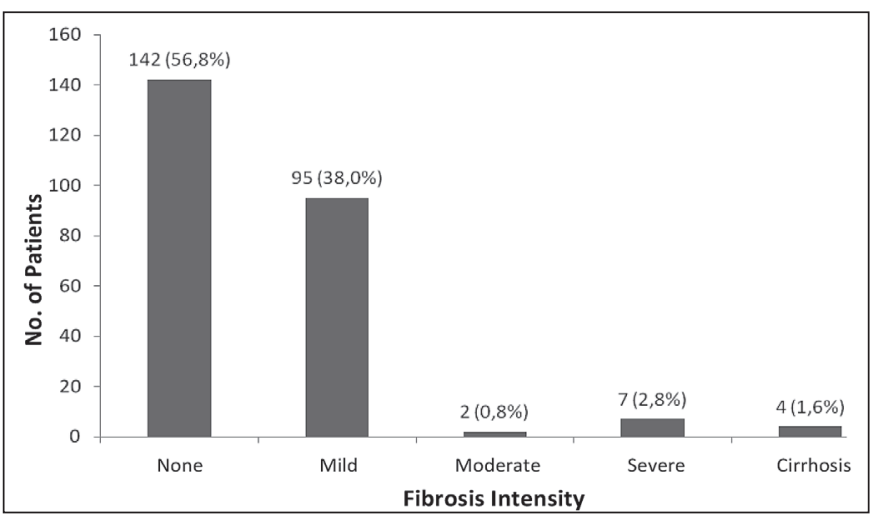

FIGURE 3. Sample distribution with regard to the presence and intensity of fibrosis

There was a moderate correlation between the degree of steatosis and the level of inflammatory activity/ballooning $\left(r_{s}=0.460 ; P<0.001\right)$ and also a regular correlation between the degree of activity and the degree of fibrosis $\left(\mathrm{r}_{\mathrm{s}}=0.583\right.$; $P<0.001$ ) (Figures 4 and 5).

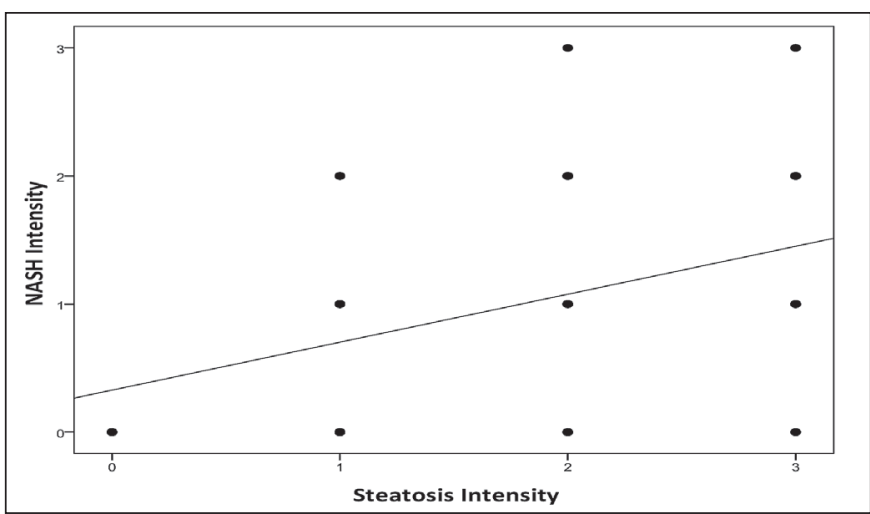

FIGURE 4. Association between steatosis intensity and nonalcoholic steatohepatitis (NASH) intensity measured by the Spearman correlation coefficient $\left(r_{\mathrm{s}}=0.460 ; P<0.001\right)$

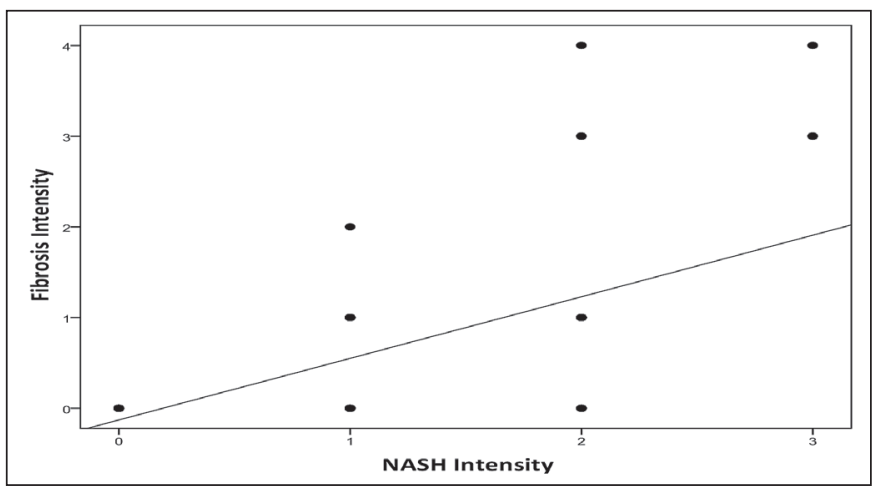

FIGURE 5. Association between nonalcoholic steatohepatitis (NASH) intensity and fibrosis intensity measured by the Spearman correlation coefficient $\left(\mathrm{r}_{\mathrm{s}}=0.583 ; P<0.001\right)$
Iron deposits were found in mild concentration in 13 $(5.2 \%)$ samples, being that in 9 the iron was located in the Kupffer cells and in 7 in the hepatocytes.

\section{DISCUSSION}

The results of this study show a prevalence of $90.4 \%$ of NAFLD in patients with $\mathrm{MO}$ who underwent bariatric surgery. This result is consistent with the literature that reports a prevalence of $84 \%$ and $96 \%$ of NAFLD in these patients ${ }^{(4)}$.

NAFLD has a wide spectrum of alterations that range from SS to fibrosis and eventually to cirrhosis. Within these alterations, this analysis shows that the degree of steatosis was distributed almost uniformly in the samples $(30.4 \%$, $28.4 \%$ and $31.6 \%$ ), for mild, moderate and severe degree respectively. Concomitantly, NASH was found in approximately $70 \%$ of the sample, there being a moderate correlation with the degree of steatosis. This finding is consistent with the physiopathology of NAFLD, in which excess fat in the hepatocyte triggers the inflammation process, leading to $\mathrm{NASH}$, which can result in fibrosis ${ }^{(24)}$. However, this correlation was not strong, since some cases showed intense degree of steatosis with mild or no inflammation, a fact that shows that the liver biopsy, before providing a definitive diagnosis, mainly reflects a stage of evolution of NAFLD.

On analyzing the degree of fibrosis of the samples of this investigation, it was noticed that fibrosis was already present in $48.3 \%$ of them; out of these, $38 \%$ were mild and only $4.4 \%$ (11 cases) were considered of intense degree. In recent years, bariatric surgery has become an important therapeutic option for MO. Some studies document a significant reduction of fibrosis in liver biopsies conducted during the surgery and after weight loss in these patients ${ }^{(5,10,13,15)}$. However, the same works report that, if the degree of fibrosis is advanced, the chances of regression reduce, moreover, there is an increase in morbimortality after bariatric surgery in patients with advanced fibrosis.

Some studies have been conducted to evaluate clinical lab parameters with histopathological findings. Liew et al. presented retrospective results of 152 patients subjected to laparoscopic bariatric surgery, in which the insulin resistance (IR), evaluated by the HOMA-IR index, was correlated with the diagnosis of $\mathrm{NASH}^{(8)}$. In a prospective study, with sequential biopsies, Mathurin et al. observed the effects of bariatric surgery on NAFLD and NASH. These authors showed an improvement in all histological and lab parameters in NAFLD in 5 years. It is interesting to note that the improvement in IR, which occurs in the first year after surgery, is a predictive factor of regression of the histological and lab parameters of NAFLD ${ }^{(10)}$. In fact, the hepatic lesion and $\mathrm{Fb}$ cannot be detected by image or lab tests. Some works have sought to identify clinical/lab markers of NASH, like age, obesity, diabetes mellitus (DM), systemic arterial hypertension, inflammation markers, aspartate aminotransferase (AST)/alanine aminotransferase (ALT) ratio $>1$ and triglyceride (TG) levels $>150 \mathrm{mg} / \mathrm{dL}$. The studies that try to correlate inflammatory markers, like some cytokines and others of oxidative stress present various results ${ }^{(7,19,16)}$. 
To date, there is no lab marker for diagnosis and gravity of NASH. In this wise, liver biopsy should perhaps be indicated, in select cases, in the pre-operative evaluation of patients with $\mathrm{MO}$ and indication of bariatric surgery. Although this indication is already described, to patients with NAFLD and with risk factors to NASH, in the last consensus of the American Association for Study of Liver Diseases, it is important to develop protocols with specific outlining, aiming at shedding light on this controversy ${ }^{(3)}$.

Some authors support that the presence of $\mathrm{Fe}$ in the liver tissue is a possible factor involved in the genesis of the inflammation ${ }^{(17)}$. The excess Fe not linked to transferrin is removed from circulation by the hepatocyte by operation of a peptide called hepcidin, which regulates the homeostasis of $\mathrm{Fe}^{(6)}$. The Kupffer cells (KC) also play an important role in the elimination of iron, since they accumulate this ion when the hepatocytes are saturated. It is possible that the $\mathrm{KC}$, when saturated with $\mathrm{Fe}$, lose control over other aggressions suffered by the liver (virus, alcohol, etc.), favoring the progression of fibrosis ${ }^{(17)}$. In the casuistic of this study, mild deposits of $\mathrm{Fe}$ were found in only $10(4 \%)$ cases, without predominance in hepatocytes or in KC. It does not seem, however, that Fe has an important role in the physiopathogeny of NASH. Corroborating our results, the study by Zamin et al. did not establish correlation between mutation of the $\mathrm{C} 282 \mathrm{Y}$ and $\mathrm{H} 63 \mathrm{D}$ gene (mutation involved in the genesis of hemochromatosis), in 20 patients with NASH. This reinforces the nonparticipation of $\mathrm{Fe}$ deposits in the physiopathology of $\mathrm{NASH}^{(23)}$.

In conclusion, the findings of this investigation confirm a high prevalence of SS and NASH in patients with MO. The correlation between NASH and fibrosis reinforce the indication of bariatric surgery in the treatment of $\mathrm{MO}$ and the importance of liver biopsy in the pre-operative evaluation of some patients. Moreover, the low prevalence of iron deposits in the samples analyzed herein makes the participation of $\mathrm{Fe}$ in the physiopathogeny of NAFLD questionable.

Losekann A, Weston AC, Carli LA, Espindola MB, Pioner SR, Coral GP. Doença hepática gordurosa não alcoólica em pacientes com obesidade mórbida, submetidos à cirurgia bariátrica. Arq Gastroenterol. 2013,50(4):xxx.

RESUMO - Contexto - A doença hepática gordurosa não alcoólica engloba um espectro de alterações histopatológicas que abrangem desde a esteatose simples até a esteato-hepatite não alcoólica. Trabalhos sugerem que depósitos de ferro (Fe) no fígado estão envolvidos na fisiopatologia da esteato-hepatite não alcoólica. Objetivo - Determinar a prevalência de esteatose simples e de esteato-hepatite não alcoólica nos pacientes com obesidade mórbida, submetidos à cirurgia bariátrica e estabelecer uma correlação dos achados anatomopatológicos com a presença de fibrose hepática. Método - Foram analisadas 250 biópsias hepáticas realizadas no transoperatório das cirurgias. Resultados - A esteatose esteve presente em 226 (90,4\%) das amostras, sendo $76(30,4 \%)$ classificadas como leves; 71 (28,4\%), como moderadas e, $79(31,6 \%)$ como intensas. A esteato-hepatite não alcoólica esteato-hepatite não alcoólica foi diagnosticada em 176 (70,4\%) dos casos, nos quais $120(48,4 \%)$ eram de grau leve; $50(20 \%)$ moderado e, $6(2,4 \%)$ intenso. A fibrose foi referida em $108(43,2 \%)$ biópsias, das quais $95(38 \%)$ eram leves; $2(0,8 \%)$, moderadas; $7(2,8 \%)$ intensas e, em $4(1,6 \%)$ casos, foi diagnosticado cirrose. Observou-se uma correlação entre o grau de esteatose e o nível de atividade inflamatória $\left(\mathrm{r}_{\mathrm{s}}=0,460 ; P<0,001\right)$ e entre o grau dessa atividade com o de fibrose $\left(\mathrm{r}_{\mathrm{s}}=0,583 ; P<0,001\right)$. Apenas $13(5,2 \%)$ amostras apresentaram depósitos de Fe. Conclusão - Existe uma prevalência elevada de esteato-hepatite não alcoólica nesses pacientes e uma correlação positiva dos graus de esteato-hepatite não alcoólica com a intensidade da fibrose. A baixa prevalência de depósitos de Fe encontrada torna questionável que a presença deste íon tenha alguma participação na fisiopatogenia da doença hepática gordurosa não alcoólica.

DESCRITORES - Fígado gorduroso. Cirrose Hepática. Obesidade mórbida. Cirurgia bariátrica. Distúrbios do metabolismo do ferro. 


\section{REFERENCES}

1. Brunt EM. Nonalcoholic steatohepatitis. Semin Liver Dis. 2004;24:3-20.

2. Brunt EM, Janney CG, Di Bisceglie AM, Neuschwander-Tetri BA, Bacon BR Nonalcoholic steatohepatitis: a proposal for grading and staging the histological lesions. Am J Gastroenterol. 1999;94:2467-74.

3. Chalasani N, Younossi Z, Lavine JE, Diehl AM, Brunt EM, Cusi K, Charlton M, Sanyal AJ; American Gastroenterological Association; American Association for the Study of Liver Diseases; American College of Gastroenterologyh. The diagnosis and management of non-alcoholic fatty liver disease: practice guideline by the American Gastroenterological Association, American Association for the Study of Liver Diseases, and American College of Gastroenterology. Gastroenterology. 2012;55:2005-23.

4. Clark JM. The epidemiology of nonalcoholic fatty liver disease in adults. Journal of clinical gastroenterology. 2006;40:S5-10.

5. de Andrade AR, Cotrim HP, Alves E, Soares D, Rocha R, Almeida A, Almeida $\mathrm{CG}$, de Freitas LA. Nonalcoholic fatty liver disease in severely obese individuals: the influence of bariatric surgery. Ann Hepatol. 2008;7:364-8.

6. Fleming RE, Ponka P. Iron overload in human disease. N Engl J Med. 2012;366:348-59.

7. Harrison SA, Kadakia S, Lang KA, Schenker S. Nonalcoholic steatohepatitis: what we know in the new millennium. Am J Gastroenterol. 2002;97:2714-24.

8. Liew PL, Lee WJ, Lee YC, Wang HH, Wang W, Lin YC. Hepatic histopathology of morbid obesity: concurrence of other forms of chronic liver disease. Obes Surg. 2006;16:1584-93.

9. Marquezine GF, Oliveira CM, Pereira AC, Krieger JE, Mill JG. Metabolic syndrome determinants in an urban population from Brazil: social class and gender-specific interaction. Int J Cardiol. 2008;129:259-65.

10. Mathurin P, Hollebecque A, Arnalsteen L, Buob D, Leteurtre E, Caiazzo R, Pigeyre M, Verkindt H, Dharancy S, Louvet A, Romon M, Pattou F. Prospective study of the long-term effects of bariatric surgery on liver injury in patients without advanced disease. Gastroenterology. 2009;137:532-40.

11. Mendler MH, Turlin B, Moirand R, Jouanolle AM, Sapey T, Guyader D, Le Gall JY, Brissot P, David V, Deugnier Y. Insulin resistance-associated hepatic iron overload. Gastroenterology. 1999;117:1155-63.

12. Misra A, Khurana L. Obesity and the metabolic syndrome in developing countries. J Clin Endocrinol Metab. 2008;93:S9-30.
13. Moretto M, Kupski C, da Silva VD, Padoin AV, Mottin CC. Effect of bariatric surgery on liver fibrosis. Obesity Surgery. 2012;22:1044-9.

14. Mosko JD, Nguyen GC. Increased perioperative mortality following bariatric surgery among patients with cirrhosis. Clin Gastroenterol Hepatol. 2011;9:897-901.

15. Mummadi RR, Kasturi KS, Chennareddygari S, Sood GK. Effect of bariatric surgery on nonalcoholic fatty liver disease: systematic review and meta-analysis. Clin Gastroenterol Hepatol. 2008;6:1396-402.

16. Musso G, Gambino R, Cassader M, Pagano G. Meta-analysis: natural history of non-alcoholic fatty liver disease (NAFLD) and diagnostic accuracy of non-invasive tests for liver disease severity. Ann Med. 2011;43:617-49.

17. Pietrangelo A. Iron in NASH, chronic liver diseases and HCC: how much iron is too much? J Hepatol. 2009;50:249-51.

18. Sebastiani G, Vario A, Ferrari A, Pistis R, Noventa F, Alberti A. Hepatic iron, liver steatosis and viral genotypes in patients with chronic hepatitis C. J Viral Hepat. 2006;13:199-205.

19. Uysal S, Armutcu F, Aydogan T, Akin K, Ikizek M, Yigitoglu MR. Some inflammatory cytokine levels, iron metabolism and oxidan stress markers in subjects with nonalcoholic steatohepatitis. Clin Biochem. 2011;44:1375-9.

20. Vyberg M, Ravn V, Andersen B. Pattern of progression in liver injury following jejunoileal bypass for morbid obesity. Liver. 1987;7:271-6.

21. White DL, Kanwal F, El-Serag HB. Association Between Nonalcoholic Fatty Liver Disease and Risk for Hepatocellular Cancer, Based on Systematic Review. Clin Gastroenterol Hepatol. 2012;10:1342-59 e2.

22. Yamauchi T, Kamon J, Waki H, Terauchi Y, Kubota N, Hara K, Mori Y, Ide T, Murakami K, Tsuboyama-Kasaoka N, Ezaki O, Akanuma Y, Gavrilova O, Vinson C, Reitman ML, Kagechika H, Shudo K, Yoda M, Nakano Y, Tobe K, Nagai R, Kimura S, Tomita M, Froguel P, Kadowaki T. The fat-derived hormone adiponectin reverses insulin resistance associated with both lipoatrophy and obesity. Nat Med. 2001;7:941-6.

23. Zamin I Jr, Mattos AA, Mattos AZ, Migon E, Bica C, Alexandre CO. Prevalence of the hemochromatosis gene mutation in patients with nonalcoholic steatohepatitis and correlation with degree of liver fibrosis. Arq Gastroenterol. 2006;43:224-8.

24. Zangar RC, Novak RF. Effects of fatty acids and ketone bodies on cytochromes $\mathrm{P} 4502 \mathrm{~B}, 4 \mathrm{~A}$, and $2 \mathrm{E} 1$ expression in primary cultured rat hepatocytes. Arch Biochem Biophys. 1997;337:217-24. 